\title{
„Ludzie czarni od słońca i osmaleni od wiatru, o spojrzeniu straszliwym i groźnym" - wojownicy husyccy w świetle źródeł z epoki
}

\begin{abstract}
Streszczenie. W historii czeskiego oręża jedno z najważniejszych miejsc zajmuje okres rewolucji husyckiej lat 1419-1436. Jest to też niewątpliwie czas wielkiej chwały husyckich wojsk polnych „sierotek” i „taborytów”, którym przez półtorej dekady nie była w stanie sprostać żadna ze stających z nimi do konfrontacji ówczesnych armii. Przedmiotem badań nie będzie jednak uzbrojenie tych wojowników, lecz ich wygląd oraz czyny, przede wszystkim te pozamilitarne, które bardzo szybko przysporzyły im złowrogiej sławy. Nierzadko paraliżowała ona całe armie oraz obrońców zamków i miast - wystarczył dźwięk słów ich bojowej pieśni Ktož jsú boži bojovníci. Ich swego rodzaju „znakami rozpoznawczymi” były: palenie i burzenie klasztorów i kościołów, tortury i mordy na ludności wsi i miast ze szczególnym upodobaniem palenia na stosie lub w stodołach oraz rabowanie wszelkich dóbr ruchomych i nieruchomych oraz handel nimi. I mimo że w średniowieczu takie postępowanie nie należało do rzadkości, to jednak ,łatka” pozbawionych litości grabieżców była bardzo chętnie przypinana właśnie husytom.
\end{abstract}

Słowa kluczowe: Królestwo Czech, husyci, rewolucja husycka, średniowiecze, wojna.

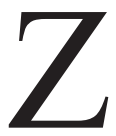

apewne w 1415 r. papież Jan XXIII nie przypuszczał, że doprowadzając na soborze w Konstancji do spalenia na stosie Jana Husa, wywoła za kilka lat wielki religijny konflikt, którego papiestwu i sprzyjającemu mu obozowi Zygmunta Luksemburskiego nie uda się zażegnać przez półtorej dekady. Pozornie wydawało się, że ruch, który uważano za heretycki, udało się zdławić w zarodku, doprowadzając do śmierci jego głównego propagatora. Jednak już w 1419 r., wraz ze śmiercią króla Wacława IV, nastąpiła prawdziwa eksplozja ruchu husyckiego. Cały ten burzliwy okres historii czeskich ziem ${ }^{1}$ można bardzo

* Wydział Filozoficzno-Historyczny, Instytut Archeologii, Katedra Archeologii Historycznej i Bronioznawstwa, e-mail: piotr.strzyz@uni.lodz.pl.

${ }^{1}$ Cf. F. Šm a he 1, Husitská revoluce, t. III (Kronika válečných let), wyd. 2, Praha 1996. 
zwięźle scharakteryzować cytatem z Kroniki bardzo pięknej o Janie Žižce: „I tak się strona przeciw stronie nastawiła, i ta strona, która zwyciężała, ta okrutnie i bez litości mordowała albo paliła, albo inną rozliczną śmierć zadawała, lecz kogo Bóg raczył ocalić, ten żyw został. A zwłaszcza Niemcy Czechów tępili, a Czechowie Niemców. I ta walka trwała okrutne 14 lat"’. Przez ten długi czas tereny głównie Czech, ale również Moraw, Śląska, jak i dzisiejszej Słowacji czy południa Niemiec, były areną ciągłych pochodów wojsk, nieustających najazdów połączonych z paleniem wsi i miast, mordowaniem ludności oraz rabowaniem dobytku. Przedmiotem artykułu będą wojownicy husyccy, ich czyny oraz charakterystyka wojsk, których złowroga sława, nierzadko paraliżowała całe armie oraz obrońców zamków i miast na sam dźwięk ich bojowej pieśni.

Oczywiście, jak w każdej wojnie religijnej, utworowi temu przyświecały doniosłe cele i idee. Szczytne założenia ruchu oddają jego fragmenty: „Kim są Boży bojownicy i ich prawo, wołają do Boga pomocy i ufają mu, tak że wreszcie zawsze z Nim zwyciężycie! [...] Wy żebracy i draby pamiętajcie o duszy, dla łakomstwa i łupieży życia nie poświęcajcie i na korzyściach się nie opierajcie””. „Boży bojownicy” mieli zatem skupiać się na głoszeniu nowych idei (najważniejszym punktem była możliwość spożywania ciała Chrystusa pod dwiema postaciami, tj. chleba i wina, oraz wygłaszania kazań w języku narodowym), przedkładając je nad korzyści materialne i dobra doczesne.

Ustanowienie nowego porządku wymaga rozprawienia się ze starym. Rewolucji husyckiej towarzyszy przez cały okres jej trwania niszczenie (grabienie, palenie, burzenie itd.) wszelkich kościołów i klasztorów uosabiających dawny porządek chrześcijański. Jak wyjaśnił to kronikarz Wawrzyniec z Brzezowej, były one uznawane za siedzibę łotrów, a założono je przeciw prawu Chrystusowemu, ponieważ Chrystus nauczał, by księża nie zamykali się w budynkach, ale głosili Słowo Boże ludziom na całym świecie ${ }^{4}$.

„I kiedy tak się stało, że król Wacław umarł, już nazajutrz, w czwartek, wtargnął wściekły tłum, ponieważ już nie miał się kogo bać, do kościołów, w których nie podawali [komunii] pod dwoma postaciami [tj. chleba i wina], i do domów

${ }^{2}$ „I tak se jest strana proti straně zazlila, kteráž strana přemohla, ta jest ukrutně bez milosti zamordovala neb zapálila neb rozličnú smrtí zahubila, leč koho sám Buoh ráčil zachovati, ten živ zuostal. A zvláště Němci Čechy hubili a Čechové Němce. A ta jest válka stála ukrutně XIV let”. Kronika velmi pěkná o Janu Žižkovi, [w:] Staročeské vojenské rády: Hájek - Vlček - Žižka, wyd. F. Svejkovský, wstęp J. Durdík, Praha 1952, s. 30. Jeśli nie zaznaczono inaczej, thumaczenia tekstów na język polski pochodzą od autora.

3 „Ktož jsú boží bojovníci a zákona jeho, prostež od Boha pomoci a úfajte v něho, že konečně vždycky s ním svítězíte! [...] Vy pakosty a drabanti, na duše pomněte, pro lakomstvie a lúpeže životóv netrat'te a na kořistech se nezastavujte!". E. S i a tkow ska, J. Si atkow ski, Wybór tekstów staroczeskich, wyd. 2, Warszawa 1988, s. 123-124; Duchem i mečem. Čtení o slavě, velikosti a utrpení našeho lidu, oprac. F. Heřmanský, Praha 2008, s. 381-382.

${ }^{4}$ Vavřinec z Březove, Husitská kronika, wyd. M. Bláhova, F. Heřmanský, Praha 1979, s. 119. 


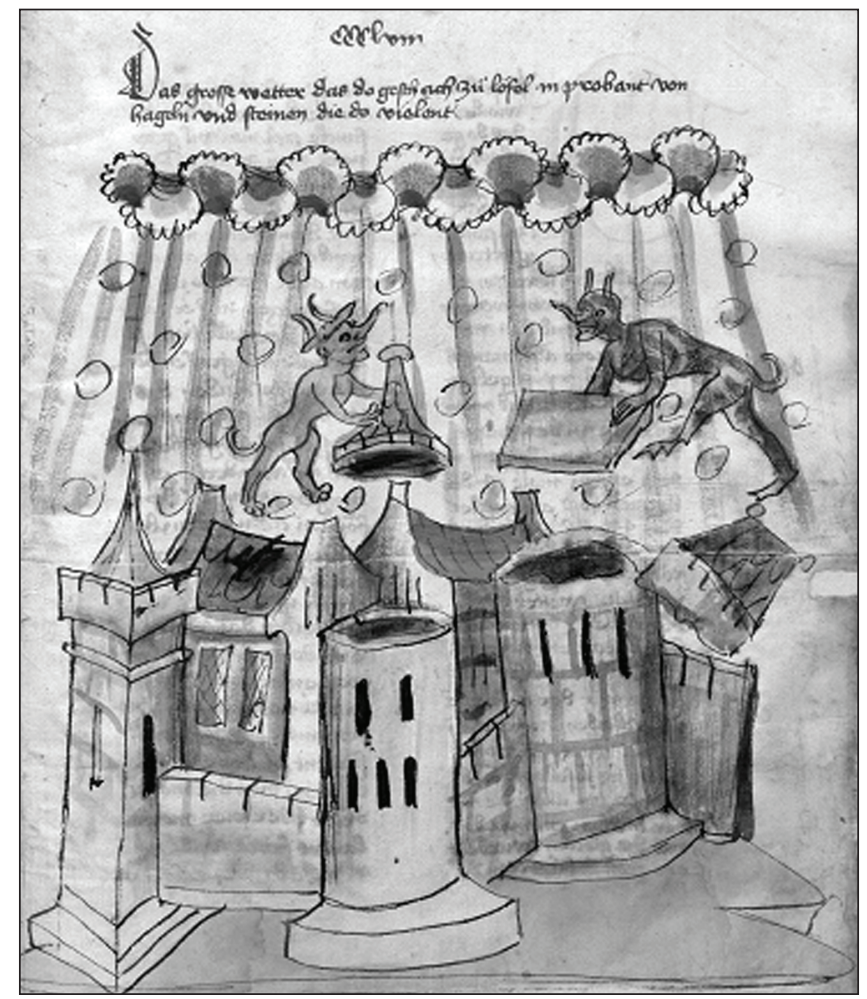

1. Symboliczne niszczenie kościołów przez szatana (Źródło: Eberhard Windecke, Geschichte des Kaisers Sigismund, Biblioteka Narodowa, Wiedeń Cod. 13975, ok. 1445-1450, fol. 432r)

księży i niszczyli organy i rzeźby. Zachęceni ku temu przez księży burzyli i klasztory - najpierw Kartouzy, klasztor bardzo piękny, który założył król Jan [Luksemburski] i który został wybudowany wielkim kosztem, ten spalili już w piątek po królewskiej śmierci, a potem do fundamentów zburzyli. [...] A jeden bluźnierca ubrał się w poświęconą szatę i szedł w niej do Pragi, a gdy to Prażanie zobaczyli, ucięli mu głowę. Tak zburzyli Břevnov, Strahov, Plasy koło Pragi, same bardzo piękne klasztory..."

5 „A když se stalo, že král Václav zemřel, hned nazítří, ve čtvrtek, vrhl ten vzteklý dav, když už se neměl koho bát, na kostely, ve kterých nepodávali pod obojí způsobou, i na kněžské domy a ničili varhany a sohy. Pobízeni k tomu kněžími bořili pak i kláštery - nejprve Kartouzy, klášter velmi krásný, který založil král Jan a který był stavěn s velkými náklady; ten vypálili hned v pátek po králově smrti a potom do základů zbořili [...] A jeden rouhač si oblékl posvátné roucho a šel v něm do Prahy, a když to Pražané uviděli dali mu useknout hlavu. Pak pobožili Břevnov, Strahov, Plasy u Prahy, samé velmi krásné kláštery...”. Ze starých latopisů českých, ed. J. Porák, J. Kašpar, Praha 1980, s. 55. 
Jak w szczegółach wyglądało to grabienie majątku kościelnego, ten sam autor podaje w opisie dotyczącym dziejów klasztoru w praskiej dzielnicy Smíchov: „A wreszcie wieczorem weszli do klasztoru Kartouzy i zrabowali w nim wszelki majątek, opili się tam różnymi napojami alkoholowymi a nadmiar wylali na ziemię, wszystkich zakonników tego klasztoru pojmali i doprowadzili ich pod eskortą z wielkim krzykiem i hałasem przez most do staromiejskiego ratusza. [...] A na drugi dzień, w św. Agapita, który był trzecim dniem po śmierci króla Wacława, płomienie zniszczyły ten klasztor w Kartouzach, tak że zostały z niego tylko mury"'.

Takie wydarzenia miały miejsce, mimo że artykuły wojskowe wyraźnie zakazywały niszczenia świątyń, a za nieposłuszeństwo w tym względzie groziła surowa kara. Jednak, co istotne w tym przypadku, chodzi tylko o niszczenie wbrew woli hetmana dowodzącego wyprawą: „Kościołów i klasztorów żadnych aby nie rozbijano ani nie palono bez zgody hetmanów za to odpowiedzialnych. I aby zawsze rzeczy poświęconych, jak ornaty, kielichy, dzwony, księgi i inne ozdoby kościelne, a zwłaszcza ciała Bożego nijak nie ruszano ani nie zabierano. Zatem kto by kościół zniszczył, temu będzie ręka ucięta. Gdyby zaś ktoś ciało Boże z puszki albo inna świętość wziął i wysypał, ten będzie bez litości spalony"7.

Innym znakiem rozpoznawczym oddziałów husyckich miało być szczególne okrucieństwo, którego przede wszystkim doświadczała ludność terenów, które stały się obiektem łupieżczych „,wspaniałych pochodów” (,spanilých jízd”). Przykładów opisujących tego rodzaju zdarzenia jest bardzo wiele. W 1419 r.: „W tym czasie mieszczanie Kouřimia wpuścili do swego miasta królewską stronę, pochwycili wyznaczonych mieszczan [...]. Wieczorem ich ścinali i wrzucali do masowego grobu; gdy ucięli głowę jednemu biedakowi, jego głowa, jak skakała po ziemi, trzykrotnie powiedziała »Krew Boża! Krew Boża! Krew Boża!«. Ale Jan Svichovský tak nakazał tych ludzi torturować: rozkazał przywiązać nieszczęsnego chrześcijanina do deski i nasypać mu do gardła prochu strzelnego; jak ten proch zapalili tak płomień przebiegł mu przez trzewia i wyleciał zadkiem na zewnątrz"s.

${ }^{6}$ „A konečně navečer vnikli do kartouzského kláštera a olupili ho takřka o všechen majetek, opili se tam rozličnými nápoji a zbytek vylili na zem, všechny řeholníky toho kláštera zajímali a dovedli je v průvodu se silným křikem a hřmotem přes most na Staroměstskou radnici [...]. A nazítŕí, totiž v den sv. Agapita, což byl třetí den po smrti krále Václava, plameny ohně zničili ten kartouzký klášter, takže z něho zůstaly jenom zdi”. Vavřine c z Březove, op. cit., s. 33. Dalej kronikarz ten podaje też długą listę klasztorów spalonych w 1420 r., ibidem, s. 119, 121.

7 „Kostelové a klášterové aby žadní vybíjeny nebyli ani vypalováni, leč by bylo rozkázáno hajtmany k tomu zřiezenými. A proto vždy aby posvátnými věcmi, jakožto ornáty, kalichy, zvony, kniehami i jinými okrasami kostelními a zvláště pak tělem Božím nikakéž nebylo hýbáno ani bráno. Nebo ktož by který kostel vybil, takovému bude ruka ut'ata. Pakli by kto tělo Božie s puškú aneb kterú jinú svátost vzal a vysypal, takový bude bez milosti upálen”. Jan Hájek z Hodětína, Vojenské zřizení, [w:] Staročeské vojenské rády..., s. 37.

8 „Tehdy také Kouřimští vpustili do svého města královskou stranu, pochytali významnější měšt'any [...]. Navečer je stínali a házeli do šachty; když usekli hlavu jednomu ubožákovi, jeho 


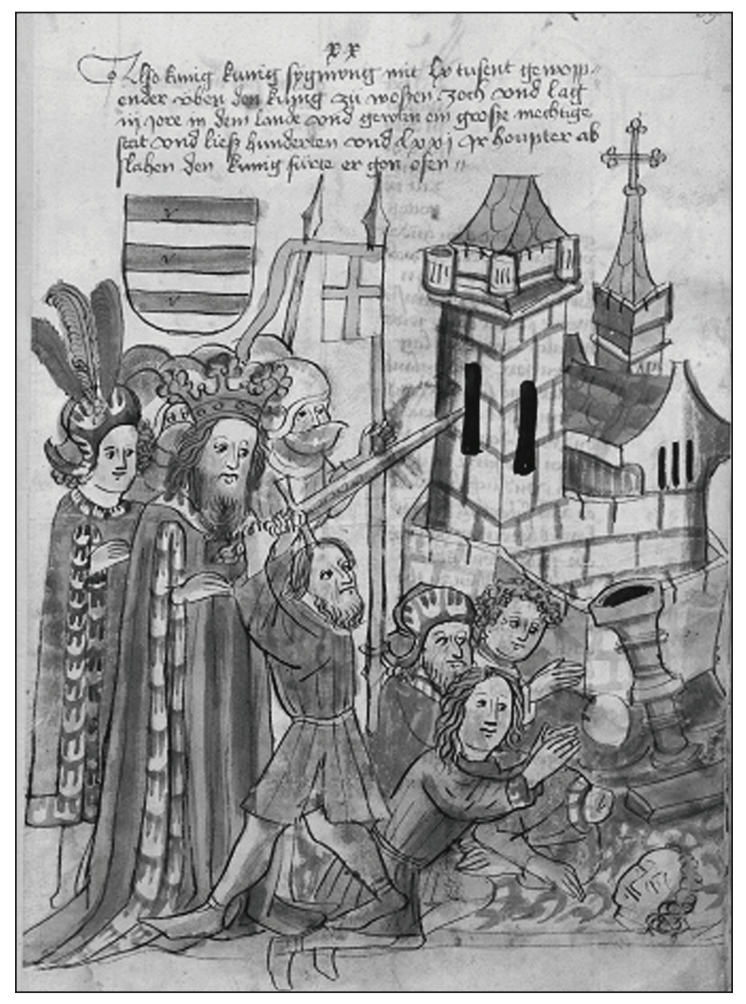

2. Scena ścinania jeńców

(Źródło: Eberhard Windecke, Geschichte des Kaisers Sigismund, Biblioteka Narodowa, Wiedeń

Cod. 13975, ok. 1445-1450, fol. 39r)

W momencie, gdy do Czech zaczęły docierać wyprawy odwetowe, posługiwano się takimi samymi metodami. W 1420 r. miasteczka Police, Nachod i Trutnov dotknął najazd wojsk śląskich, które ,zabiły wiele ludzi obojga płci a około czterdziestu dzieciom ucięli prawą nogę i lewą rękę, lub lewą rękę i prawą nogę, a niektórym jeszcze ucięli i nosy"9.

hlava, jak tak skákala po zemi, třikrát za sebou pravila: »Krev boži! Krev boži! Krev boži!«. Ale Jan Svichovský takto přikazoval ty lidi mučit: rozkázal přivázat nebohého křest'ánka k prknu a nasypat mu do hrdla střelný prach; pak ten prach zapálili a ten plamen prolétl všemi střevy, až vyletěl zadkem ven”. Ze starých latopisů českých..., s. 58.

9, ,[...] pobili přemnoho lidí obojího pohlaví a asi čtyřiceti dětem usekali pravou nohu a levou ruku nebo levou nohu a pravou ruku a některým také ještě uřezali i nosy”. Va vř in e c z B ř e z ové, op. cit., s. 236. Podobne wydarzenia, ale też i wieszanie kobiet na płotach, przytacza kronikarz podczas opisu pochodu wojsk Zygmunta Luksemburskiego przez Humpolec w 1421 r. Cf. ibidem, s. 273-274. Z kolei wojska śląskie, które w 1421 r. zdobyły miasteczka Poličko i Ostaš, miejscowej ludności masowo wyrywały języki. Cf. Ze starých latopisů českých..., s. 79. 
Terrorowi na ludności cywilnej towarzyszyły oczywiście grabieże mająt$\mathrm{ku}$ - pieniędzy, cennych przedmiotów, broni, ale także inwentarza domowego i zboża. Podobnie jak w przypadku niszczenia posiadłości kościelnych, także tutaj artykuły wojskowe surowo zabraniały tego rodzaju praktyk: „Domów aby nie niszczyli, dobytku ani koni aby im nie zabierali ani do wojska nie wodzili. [...] Także gdzie się wojsko rozłoży obozem, aby chałup i dworów ludziom nie niszczyli i nie burzyli, i takich niechrześcijańskiej zguby aby ludziom nie czynili”"10.

Szczególnie zakazywano łupienia posiadłości ludności, która wspierała idee ruchu husyckiego: ,przyjaciołom jeśli ktoś będzie zabierał inne rzeczy niż skromny pokarm dla siebie i koniom obrok, taki karany będzie jako łupieżca. [...] Koni, krów i innego dobytku a szat przyjaciołom aby nie zabierać, ani innych rzeczy, które do gospodarstwa przynależą, gdyż taki będzie karany jako łupieżca"11.

Artykuły i zalecenia wojskowe nie były jednak często przestrzegane w wojennej rzeczywistości. Na początku rozruchów w Pradze w 1419 r.: „Na Nowym Mieście [w Pradze] dwa dni stali [...]. Potem się zwrócili przeciwko Żydom a wszystko im pokradli i pozabierali [...]. Potem wytłukli wszystkie domy księży; mistrzów [uniwersyteckich], którzy nie uciekli, zebrali i osadzili w więzieniu w ratuszu"12.

Praktyki grabienia wszystkiego, co się dało, utrzymały się aż po sam schyłek rewolucji, czego dowodzą opisy z oblężenia Pilzna z lat 1433-1434: „I kiedy oblegali Pilzno, za bardzo pustoszyli czeskie ziemie i poczynili w kraju wielką drożyznę, ponieważ przyjeżdżali do kościołów i wsi, zabierali ludziom wszystko, co mieli w stodołach i odwozili to dokądkolwiek, każdy do swego domu; niektórzy to wnet sprzedawali"'13.

W podobny sposób przedstawia to, nieprzychylny husytom, Bartoszek z Drahonic: „Tegoż roku, jeszcze w roku 1433 w czasie, gdy wymienione wojska obozowały pod Pilznem w pięciu taborach, czyli na pięciu pozycjach, rozesłali husyci swych ludzi do różnych czeskich krain i ci wielokrotnie wyjechali z licznymi wozami, wymłócili obywatelom wsi i miasteczek ich zboże, przemocą pobrali bydło, trzodę i liczne przedmioty z gospodarstwa, część z tego zawieźli, odnieśli

${ }^{10}$ „Chalup aby nevybíjeli, dobytka ani koní aby jim nezajímali, ani ven z vojska nevodili. [...] Také kdež se vojsko klade, aby chalup a dvoruov lidem netrhali, ani bořili, a takových nekřest'anských záhub aby nad lidmi nečinili”. Ja n Hájek z Hodětína, op. cit., s. 41.

${ }^{11}$ „Na přátelském bude-li kto bráti jiné věci nežli pokrm sobě skrovný a koňóm obrok, takový kázán bude jako lúpežník. [...] Koní, krav i jineho dobytka a šatuov na přátelském aby žádný nebral, ani jiných věcí, kteréž k hospodářství př́slušejí; neb takový kázán bude jako lúpežník". Ibidem, s. 37.

12 „Na Nové Městě ten den dva stali [...]. Potom se vrhli na židy a všechno jim pokradli a pobrali [...]. Potom vytloukli všechny kněžské domy; mistri kteř́ neutekli, sebrali a posadili do vězení na radnici”. Ze starých latopisù českých..., s. 82.

${ }^{13}$ „A když obléhali Plzeň, přiliš plenili českou zemi a způsobili tak v zemi velikou drahotu, protože přijižzěli do kostelů a osad, brali lidem všechno, co měli ve stodolách, a odváželi to pryč, každý do svého domova; někteří to hned prodávali”. Ibidem, s. 116. 


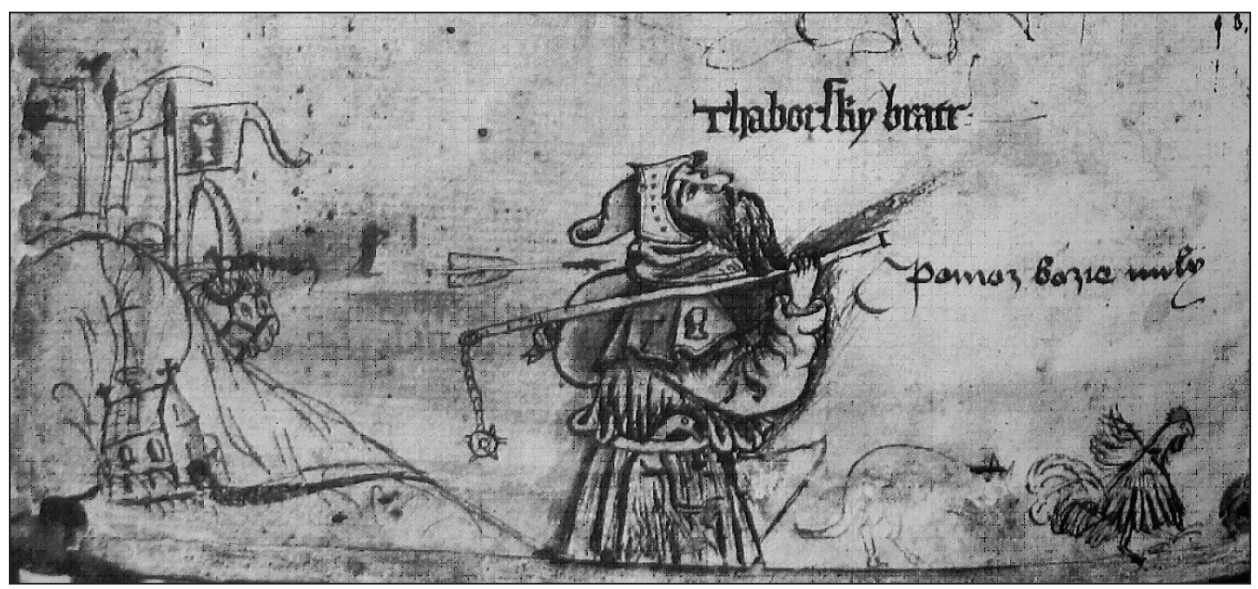

3. Taborski brat na wojennej wyprawie. Rękopis w Archiwum miasta Tábor (Źródło: P. Č or n ej, Velké dějiny zemí Koruny České, t. V, 1402-1437, Praha 2000, s. 500)

i zagnali dla wojska pod Pilznem, a część do własnych zamków i domów i przysposobili w wielu czeskich krainach niezmiernych szkód"14.

W tym miejscu jako klasyczną ilustrację takich zachowań należy wskazać na rycinę przedstawiającą taborskiego brata na wojennej wyprawie. Brodata, ubrana w głęboki kaftan postać ma przez ramię przerzucony cep, za pasem niesie zdobyczną gęś, przed nim ucieka kogut, natomiast za nim widać palący się klasztor oraz dalsze oddziały husyckie z charakterystycznym symbolem kielicha na chorągwi.

Tak ekspansywna polityka wojsk polnych „,sierotek” oraz „taborytów” w początku lat trzydziestych XV stulecia zaczęła systematycznie zniechęcać coraz większe rzesze dotychczasowych zwolenników ruchu husyckiego. Najbardziej wymownym przykładem poświadczającym ten proces jest list Bohunká z Vrhotic z wiosny 1434 r., zatem napisany zaledwie kilka miesięcy przez bratobójcza bitwą pod Lipanami (30 maja 1434 r.): „Ale nie byłem nigdy sprawcą zguby tej ziemi, bym z nimi polami jeździł, grabił, palił lub ludziom niewinnym co złego czynił [...]. I tak mi teraz taboryci trzech ludzi w Křesicích spalili a konie mi z pola zabrali. I teraz taboryckie wojsko maszerujące od Borotína i obozujące w Německém Záhoří we wsi, wszystko ludziom zabrało i zjedło co mieli zgromadzone.

${ }^{14}$ „Téhož roku a ještě v r. 1433 v době, kdy řečená vojska ležela před Plzní v pěti táborech čili na pěti místech, rozeslali husité své lidi do různých českých krajů a ti mnohokrát vyjeli s četnými vozy, vymlátili obyvatelům vsí a městeček jejich obilí, násilím pobrali skot [bydło], brav [trzodę] a rozličné předměty $\mathrm{z}$ hospodářství, něco z toho odvezli, odnesli a odehnali k vojskům před Plzní a něco $\mathrm{z}$ toho do vlastních hradů a domovů a způspbili v mnoha českých krajích nesmírnou škodu". B art oš e k z Draho n i c, Kronika, [w:] Ze správ a kronik doby husitské, oprac. I. Hlaváček, Praha 1981, s. 265; Chronicon Bartossek de Drahonicz, [w:] Fontes Rerum Bohemicarum, t. V, ed. J. Goll, Praha 1893, s. 612. 
[...] I koni tym ludziom naszym za trzydzieści kop groszy zabrali do Pilzna, obarczając mnie jeszcze winą, że z nimi pod Pilznem nie obozowałem"15. Poświadcza on, że nawet husyccy sprzymierzeńcy nie byli w swych posiadłościach bezpieczni.

Kolejnym specyficznym elementem działań wojsk husyckich było masowe palenie wsi, miasteczek, ale i miejscowej ludności. Przyjmuje się, że zabijanie ludzi w taki sposób było niejako symbolicznym odwołaniem do męczeńskiej śmierci Jana Husa na stosie. Podczas oblężenia miasta Chociebuża obiecano załodze, że gdy się podda, zostanie puszczona wolno. Jednak dowódca wojsk oblężniczych, Jan Opočenský, nie dotrzymał danego obrońcom słowa, gdyż ,gdy ich pochwycono i zapędzono do stodół - były ich pełne trzy stodoły - i podpalono. Gdy jakaś żona widziała, że jej mąż płonie, skoczyła za nim do stodoły i spaliła sie razem ze swym mężem. A tak ich tu ten pan wiarołomny zgubił na siedemset ludzi. Gromadę tę jeszcze uzupełnił czterema [setkami] w Chrudimiu. Na Horkách spalono czterdzieści osób, gdy je zagnano do jednego domu"16.

Szczegóły spalenia miasta zawiera też opis zdobycia przez Husytów w 1425 r. Radkowa (niem. Wunschilborg lub Wünschelburg) w Kotlinie Kłodzkiej. Wydarzenia te znane są z relacji Marcina Kotbusa z Bolkowa. Mieszkańcy przerażeni już samymi informacjami o marszu wojsk husyckich schronili się w wysokim, murowanym domu wójta, a zabudowania miejskie sami podpalili. Husyci wykazali się jednak dużą cierpliwością i odczekawszy, aż zabudowa się wypali, negocjacjami skłonili mieszczan do poddania się. Większość z nich wypuszczono (kobiety i dzieci), meżczyzn zaś wzięto w niewolę. Jednak księża, którzy nie chcieli przyjąć husyckiego obrządku, zostali poddani wymyślnym torturom: „pobiegł jeden i przyniósł wiązkę/snop słomy, którą otoczyli go pierścieniem naokoło ciała i opasali go tak naokoło ciała, że nie można go było zobaczyć. Następnie podpalili słomę i kazali mu biegać i tańczyć przed wojskiem z ogniem tak długo, aż umarł. A potem wzięli go nieżywego i wrzucili do warzelni pełnej gotującej się wody i wrzucili też starego księdza, proboszcza wsi i pozwolili, by obaj się gotowali. Tak to obaj ponieśli męczeństwo"17.

15 „Ale nebylt' sem nikdy zhúbce země teto, bycht' s nimi polem jezdil, bral, pálil nebo lidem newinným co zlého činil. [...] A takét' sú my nynie Táborští tři člowěky mé w Křesicích spálili a koně mi na roli pobrali. A nynie Táborské wojsko od Borotína táhnúce leželi sú w Německém Záhoří we wsi naší, a wšecko sú lidem pobrali a stráwili což sú měli. [...] A koňského pohlawie těm lidem našim w zimě za třidceti kop gr. sú pobrali ku Plzni, winu mi dáwajíce, že s nimi u Plzně neležím". Archiv Český čili stare písemné památky České i Moravské, část 7, ed. F. Kalousek, Praha 1887, s. 431. Cf. także P. Č or n e j, Lipany ve svédectví pramenů, „Husitský tabor” 1985, t. VIII, s. 155-156.

${ }^{16}$ „A pak je pochytali a nahnali do stodol - byly jich tři plné stodoly - a upálili. Když nějaká žena viděla, jak její muž hoří, skočila za ním do stodoly a uhořela se svým mužem. A tak jich tu ten pán věrolomný zahubil na sedm set. Hromádku ještě se čtyřmi dalšími popravili v Chrudimi. Na Horkách jich upálili čtyřicet, když je nahnali do jedné chalupy”. Ze starých latopisů českých..., s. 77.

17 „Do liff eyner unde brachte eine schote stro, dy bunden sy ym czu rynge umbe den leip unde groten die ym allumme den leip, das man en nicht gesehen kunde. Alzo czunten sy daz stro an un- 
Do stałego motywu palenia ludności czasami dochodzily też dodatkowe „atrakcje”. Przykładowo w 1420 r. na św. Marcina, czyli 11 listopada, oddziały Jana Žižki po zdobyciu Prachatic zagnały mieszczan do trzech domów i kaplicy, a następnie je podpalili. Ludność, którą odnaleziono jeszcze żywą, wrzucano do studni ${ }^{18}$.

Zła sława niezwyciężonych wojowników, a przy tym nieznających litości, spowodowała, że pod koniec lat dwudziestych XV w. ${ }^{19}$ często na samą wieść o pochodzie wojsk husyckich ludność pozostawiała majątek i chroniła się w lasach, a potężne armie uciekały w popłochu. Najbardziej spektakularnym przykładem jest oczywiście bitwa pod Domažlicami w zachodnich Czechach, do której doszło w 1431 r. Granicę Czech przekroczyły wówczas wojska krucjatowe, które Bartoszek z Drahonic oceniał przesadnie na 40350 jazdy oraz 90000 piechoty oraz 9000 wozów. Zaś „,przeciwko nim mężnie wyruszyli [...] ksiądz Prokop i drugi Prokop zwany Małym ze swymi wojskami, taborytami, sierotkami, wiklifistami i prażanami z trzema tysiącami jeźdźców i pięćdziesięcioma tysiącami pieszych jak się wszędzie mówiło i z wieloma działami [...]. Gdy jednak Niemcy poznali, że ci maszerują przeciwko nim, uciekli przez las za Domažlicami, niektórzy z naszych ich jednak tak ścigali przez ten las, że zabrali Niemcom, jak się wszędzie mówiło, ponad trzy tysiące wozów z większymi i mniejszymi działami w liczbie ponad stu trzydziestu i ich rozlicznymi innymi rzeczami”"20.

Informacje o tym, co zaszło pod Domažlicami, możemy odnaleźć także u Jana Długosza, który zanotował, że na wieść o pochodzie wojsk husyckich ,natychmiast

de lissen en alzo lauffen unde tantczen yn dem here mit dem fewre alzo lange bis her dirstigkte. Do nomen sie en alzo tod unde worffen en yn eyne brewpfanne vol sydendis wassiris, unde worffen ouch den alden pfaffen, den dorffpfarrer, unde lissen sie doryne syden. Alzo worden sy beyde gemartirt". Chronik des Martin von Bolkenhain, Scriptores Rerum Silesiacarum, Bd. XII (Geschichtschreiber Schlesien des XV. Jahrhunderts), hrsg. F. Wachter, Breslau 1883, s. 3. Za pomoc w thumaczeniu tekstu dziękuję prof. dr. hab. Grzegorzowi Żabińskiemu z Uniwersytetu Humanistyczno-Przyrodniczego im. Jana Długosza w Częstochowie. Na temat zdobycia Radkowa cf. F. P a la c k ý, Déjiny národu českeho $v$ Čechach a na Moravě, t. III, wyd. 3, Praha 1940, s. 752-753; P. K a r p, Niszczenie klasztorów w relacjach kronik doby wojen husyckich, [w:] Scriptura, diploma, sigillum. Prace ofiarowane profesorowi Kazimierzowi Bobowskiemu, red. J. Zdrenka, J. Karczewska, Zielona Góra 2009, s. 319.

18 Ze starých latopisù českých..., s. 69.

19 Już w 1420 r. wielki mistrz krzyżacki w liście do rajców toruńskich napisał, że husyci i kacerze zdobywają miasta i klasztory, a schwytanych chrześcijan niegodziwie mordują. $C f$. P. Karp, Polsko-husycka wyprawa zbrojna przeciw Zakonowi krzyżackiemu w roku 1433, Zielona Góra 2017, s. 74-75.

20 „Proti nim statečně vytrhli [...] kněz Prokop a druhý Prokop zvaný Malý se svými vojský, totiž s tábory, sirotky, viklefisty a pražany se třemi tisíci vozů, pěti tisíci jezdců a padesáti tisíci pěších, jak se všeobecně ř́íkalo, též s mnoha děly [...]. Když však Němci poznali, že tito postupují proti nim, utekli přes les za Domažlicemi, někteří z nich je pak pronásledovali tím lesem a vzali Němcům, jak se všeobecně ř́kalo, přes tři tisíce vozů s velkými i menšími děly v počtu dobře sto třicet a s rozličnými jejich věcmi”. B artoš ek z Drahoni c, op. cit., s. 252; Chronicon Bartossek de Drahonicz..., s. 604. 


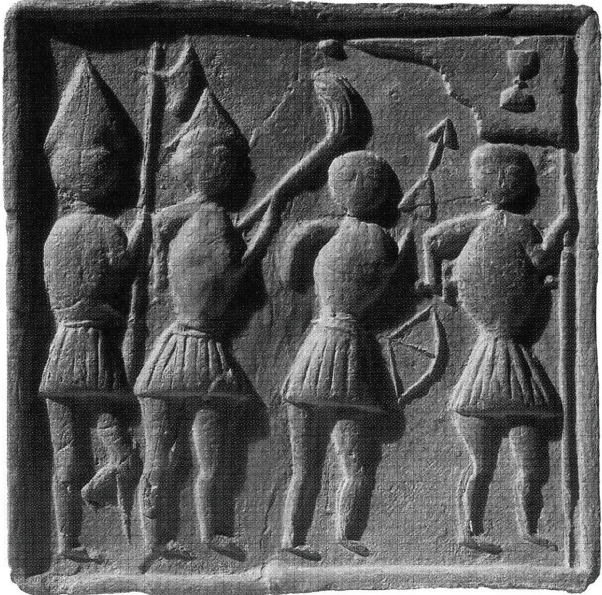

4. Przedstawienie wojowników husyckich na kaflu piecowym, zamek Lichnice, okr. Chrudim, XV w. (Źrodło: V. Bry ch, Arma diaboli. O kuši a střelcích, Praha 2012, s. 26, ryc. 4)

ogarnął Niemców, nie wiem jak wielki, strach, do którego nie było powodu. [...] Ten strach do tego stopnia ogarnął całe wojsko, że można było być przekonanym, iż siłę tak wielkiego wojska złamała sama wiadomość o przybyciu wrogów, mimo że ich jeszcze nie widziano" $"$.

Złowrogie legendy o husytach, które docierały również na tereny Królestwa Polskiego i ziem ościennych, wkrótce stały sie rzeczywistością. W 1433 r. doszło bowiem do połączonej wyprawy wojsk ,sierotek” dowodzonych przez Jana Čapka z Sán oraz wojsk polskich na posiadłości zakonu krzyżackiego w Nowej Marchii oraz w Prusach. Kronikarz J. Długosz już na wstępie opisu tych wydarzeń dokładnie scharakteryzował lęk najechanej ludności, która szczególnie miała obawy ,przed Czechami, o których wieść, co wszystko powiększa ponad stan rzeczywisty, głosiła, że są bardzo okrutni" 22 .

Przez kilkanaście lat wojska husyckie nie znalazły wśród kolejnych armii krucjatowych równego sobie przeciwnika na placu boju. Jednak postępujące wyniszczenie gospodarcze czeskich ziem, jak również nasilające się w początku lat trzydziestych XV w. klęski żywiołowe spowodowały drożyznę i coraz silniejszą polaryzację postaw społecznych ${ }^{23}$. Do militarnego rozstrzygnięcia doszło 30 maja 1434 r. pod wsią Lipany, gdzie siłom koalicji umiarkowanych

${ }^{21}$ Jana Dług os za Roczniki, czyli kroniki sławnego Królestwa Polskiego, ks. 11 i 12, Warszawa 2009, s. 56-57; J o an n is Dlug o s s i Annales seu cronicae incliti Regni Poloniae, Warszawa 2001, s. 46.

${ }^{22}$ Jana Długosza Roczniki..., s. 99; Joannis Dlugossi Annales..., s. 84: „[...] hinc Bohemorum, quos crudeles nimis fama, que omnia supra verum extollit, prodente noverant, pavore nimio perculsi”.

${ }^{23}$ Szerzej trudną sytuację gospodarczą w Czechach przed bitwą pod Lipanami omówili m.in.: P. Č or n ej, Tajemství českých kronik, Vyšehrad 1987, s. 201-203; i d e m, Velké dějiny zemí Koruny České, t. V (1402-1437), Praha 2000, s. 594-599; S. B yl in a, Rewolucja husycka, t. II (Czas chwały i czas zmierzchu), Warszawa 2015, s. 88-89. 


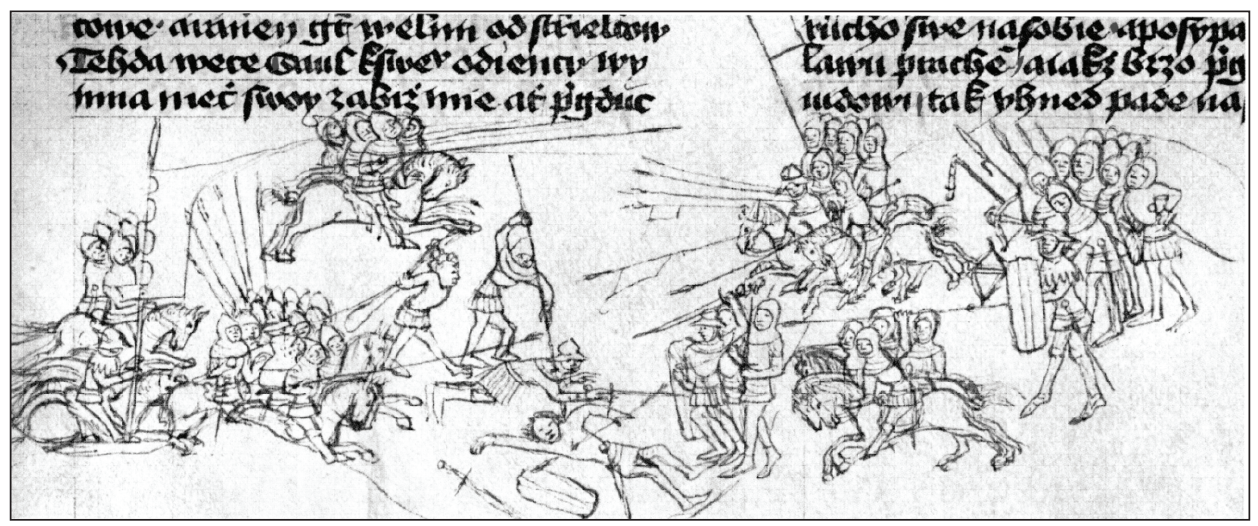

5. Bitwa husytów, tzw. Český Starý zákon, Biblioteka Narodowa w Pradze, XV w. (Źró dło: V. B ry ch, Arma diaboli. O kuši a střelcích, Praha 2012, s. 20, ryc. 25)

utrakwistów i kalikstynów (tzw. jednocie pańskej) udało się pokonać wojska polne stronnictw „sierotek” oraz „taborytów”. Zwycięzcy wzięli srogi rewanż za lata husyckich grabieży. $Z$ wielu zapisów dotyczacych tej bitwy w interesujacej nas kwestii najbardziej wartościowy, ale przy tym stronniczy, jest opis Eneasza Sylwiusza Piccolominiego, późniejszego papieża Piusa II. Przedstawiając finalny efekt bitwy, zapisał on: „Gdy bój się skończył i zebrano kilka tysięcy więźniów, Menhart [z Hradca] radę panów zwołał, i postanowili zły lud wyniszczyć. [...] ludzi czarnych od słońca i osmalonych od wiatru, o spojrzeniu straszliwym i groźnym, którzy w dymie bitewnym żyli, o orlich oczach, nieuczesanych włosach, długich brodach, smukłych ciałach, owłosionych członkach i o skórze tak twardej, że wydawało się, iż jest tak mocna jak żelazo pancerza. [...] Zatem wszyscy, którzy z Prokopem wojowali, mężowie silni a w bojach zaprawieni. [...] Weszli więc oni do stodół, które w Czechach są oblepione gliną i kryte strzechą, kilka tysięcy Taborytów i Sierotek. Zamknięto szybko drzwi i stodoły podpalono, w których wojsko ludzi tych będących sprawcami wielu bitew i rozpusty, spalone zostało i za swe czyny wzięło zapłatę"24.

Z pewnością spalenie części jeńców dowodzi zaciętości obu stron, o czym wspomniano w cytowanej na wstępie Kroniki bardzo pięknej o Janie Žižce. Na czyj rozkaz wykonano ową egzekucję, nie sposób dziś jednoznacznie rozstrzygnąć. Eneasz Sylwiusz Piccolomini jako inicjatora wskazał Menharta z Hradca. Z kolei w jednym z rękopisów Starych latopisów czeskich znajduje się informacja, że był to Jan Krk z Rábí, który chciał zemścić się w ten sposób za spalenie jego zamków: Rábí i Svihov ${ }^{25}$. Jako inicjatorów tego czynu wymieniono

${ }^{24}$ Aenae Sylvii Chronicon Bohemiae, [w:] Fontes Rerum Bohemicarum, t. VII, ed. J. Emler, Praha 1907, s. 181.

${ }^{25}$ P. Č ornej, Lipany..., s. 181, przyp. 148. 


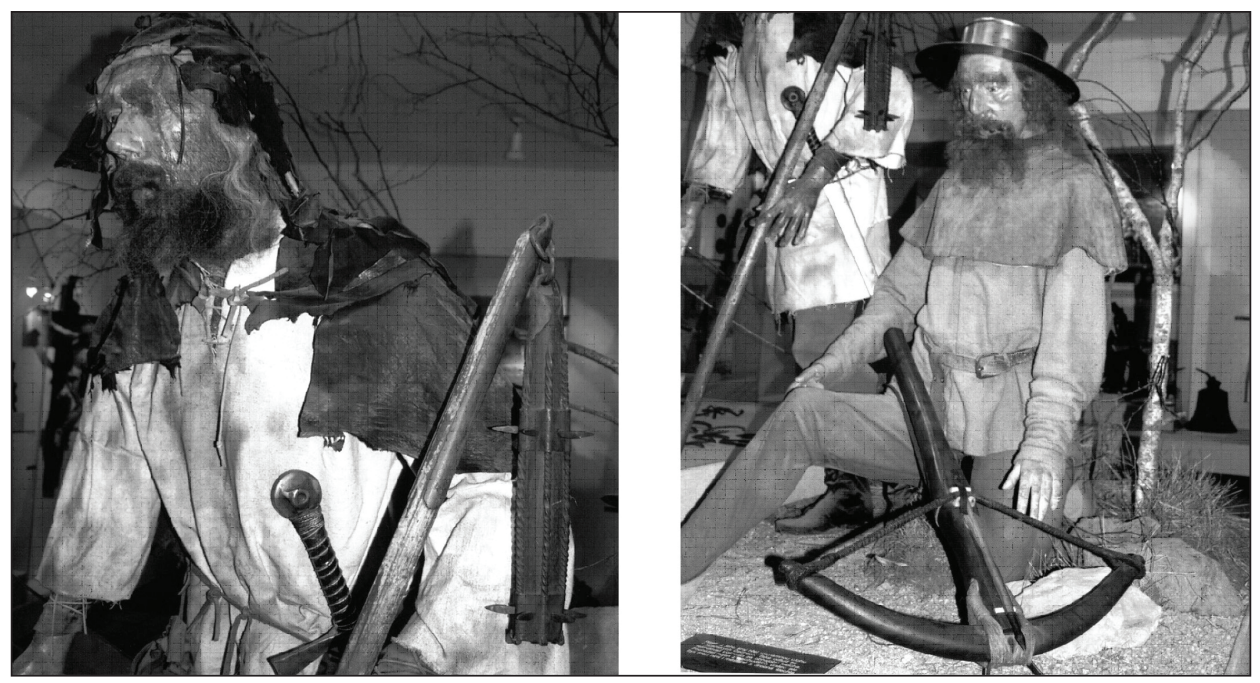

6. Rekonstrukcja postaci wojowników husyckich, Prácheňské muzem w Písku (Źródło: J. Dolej ší, L. Křížek, Husité. Vrchol válečného umění v Čechách 1419-1434, Praha 2009, s. 66-67)

też Mikuláša Krchlebca oraz mieszczan z Pilzna, którzy mieli się „odpłacić” za wielomiesięczne oblężenie i ostrzał miasta ${ }^{26}$. Określenie spalonej ludności jako „ludzi czarnych od słońca i osmalonych od wiatru” opisuje zapewne najbardziej rewolucyjny element tej armii, czyli pieszych żołdaków utrzymujących się nie tyle z samej służby wojennej, ale przede wszystkim z grabieży. Scharakteryzowanie ich jako niebezpiecznych dla przyszłego porządku w Królestwie Czeskim z pewnością, w ówczesnej sytuacji, nie było określeniem przesadnym. Prawdopodobieństwo, że po zakończeniu wojny powrócą oni np. do uprawy roli czy produkcji rzemieślniczej, było znikome. Ich eliminacja wydawała się więc zwycięzcom jak najbardziej uzasadniona. W ten sposób pozbyto się najgroźniejszego społecznie elementu.

W podobnym tonie wypowiedział się też tzw. Stary Kolegiat: „I tak zupełnie i całkowicie wymienione wojska »sierotek « $\mathrm{i}$ »taborytów《 ze swymi wozami tegoż dnia zostały pokonane od wymienionych panów i zabitych ich było w boju ponad 1200, a ci, którzy zostali pojmani w niewolę, w stodołach koło [Czeskiego] Brodu zostali spaleni, było ich ponad 900. [...] i tak ów związek owych łotrów zginął i królestwo poczęło być uspokajane"²7.

${ }^{26}$ Ibidem, s. 180-181, przyp. 147 i 149.

${ }^{27}$ „Et sic plenarie et in toto praefati exercitus Syrotkonum et Thaboritarum cum suis curribus ibidem ipso die prostrati sunt a praedictis dominis et occisi sunt ibi in campo plures, quam mille ducenti; inter quos occius est uterque sacerdos Procopius praefati. Et qui capti sunt fugientes, 
Prócz informacji z kronik na wzrastający porządek w kraju po bitwie pod Lipanami wskazują też odczucia pospolitej ludności, o czym zaświadczał np. napis na bramie zamku w Velkém Meziříčí: „Lata Bożego 1434 w niedzielę po Bożym Ciele panowie ziemscy w bitwie pokonali sierotek i taborytów polne wojska i od tej chwili ku uspokojeniu [Królestwa] się jednoczyli"28.

I tylko autor wspomnianej kilkakrotnie Kroniki bardzo pięknej o Janie Žižce ze smutkiem zapisał: „A te dwa wojska wojowały w Czechach i na Morawach i w Austrii i na Węgrzech, w Turyngii, w Marchii Brandenburskiej i w Łużycach. Także szeroko wyprawiali się do Austrii i do Prus, obozowali w Prusach i w Gdańsku, i końmi w morzu brodzili. I z wielka sławą zawsze wracali. Reszta ich między Czeskim Brodem koło Kurzimia od Czechów zginęła"29. Wyraźnie bardziej cenił militarne osiągnięcia husytów, przemilczając ich inne, mniej chwalebne czyny.

Zacytowany powyżej fragment stanowi dobre wprowadzenie do zagadnienia o wiarygodność źródeł, które opisują ówczesne wydarzenia. Znamienne jest bowiem, że większość tych informacji pochodzi od autorów sprzyjających obozowi katolickiemu lub wręcz bezpośrednio z nim związanych. Do najważniejszych źródeł narracyjnych z pewnością zalicza się kronikę Bartoška z Drahonicz. W początkowym okresie rewolucji pełnił on służbę w wojskach Zygmunta Luksemburskiego, by w latach trzydziestych XV w. zostać lennikiem jego dóbr w okolicach zamku Karlštejn ${ }^{30}$. Stronę obozu katolickiego reprezentował także autor Chronicon veteris Collegiati Pragensii, który z kolei najprawdopodobniej był mieszczaninem zamieszkałym w Pradze, być może mistrzem tamtejszego uniwersytetu. Nie krył on swej niechęci to obozu husytów, mimo że w przeszłości był z nim związany ${ }^{31}$. Wreszcie kronika Eneasza Sylwiusza Piccolominiego została napisana przez obcokrajowca, bezpośrednio związanego z papiestwem. Był on wysłannikiem soboru w Bazylei, by po kilku latach zostać wybranym na Stolicę Piotrową jako papież Pius II. Kronikę zaczął pisać pod koniec lat pięćdziesiątych wieku XV, ale z uwagi na piastowaną funkcję miał dostęp do

in horreis prope Brodam concremati sunt bene ad noningenta. [...] et sic illa coadunatio illorum latronum periit et regnum coepit pacificari”. Chronicon veteris Collegiati Pragensii, [w:] Fontes Rerum Austiacarum, Bd. II, Abt. 1, hrsg. K. Höfler, Wien 1856, s. 93-94.

${ }^{28}$ P. Č ornej, Velké déjiny..., s. 619.

${ }^{29}$ „A ty dvě vojště vždy jsú polem táhly v Čechách i v Moravě i v Rakúsiech i v Uhřicech, v Durynciech, v Macích i v Lužnicské zemi. Také jest široce táhlo vojsko do Rakus, do Prus, a leželo jest v Prusiech a v Dansku, a koně v moři brodili. Avšak jsú s velikú ctí zase přijeli. Ostaci pak mezi Brodem u Kouřima od Čechuov sú zhynuli”. Staročeské vojenské řády..., s. 35.

${ }^{30}$ „Léta Božieho MoCCCCoXXXIIIIo v tu nědeli po Božiem těle páni zemščí polem porazili sirotčie i táborská i polnie vojska a od té chvíle k uspokojenie se jednotili”. P. Č or n ej, Lipany..., s. 173; J. Dolej ší, L. Kříž ek, op. cit., s. 225.

${ }^{31}$ P. Č o r n ej, Lipanská křižovatka. Př́činy, průběh a historický význam jedné bitvy, Praha 1992, s. 131. 
wielu oryginalnych dokumentów przechowywanych w archiwum papieskim ${ }^{32}$. Szczególnie jego opisy stawiają husytów w jak najgorszym świetle.

Zabiegi te miały jeden zasadniczy cel - zdyskredytować ruch husycki w oczach społeczeństwa zachodniej Europy. Z podobną sytuacją zapewne mamy do czynienia w przypadku Wandalów, którym pisarze rzymscy przypisywali, często na wyrost, wszystkie najgorsze cechy ${ }^{33}$. Wreszcie zastanowić się należy, czy okrucieństwa, których masowo mieli dopuszczać się husyci, były na tle ówczesnej epoki czymś wyjątkowym. Oczywiście brak tutaj miejsca, aby naświetlić szerzej to zagadnienie, jednak nie ma wątpliwości, że zarówno w czasach średniowiecza, jak i w okresach wcześniejszych czy późniejszych życie ludzkie oraz wszelkie dobra doczesne nie były traktowane ze szczególną atencją. Występków takich dopuszczały się nie tylko wojska najeźdźcy, ale niejednokrotnie postępowały tak też oddziały zaciężne czy pospolitego ruszenia, które w dobrach okolicznej ludności szukały zaległej wypłaty czy potrzebnej żywności. Nierzadko dochodziło przy tym do gwałtów, mordów, podpaleń czy egzekucji jeńców. Wypada zatem stwierdzić, że husyci byli z pewnością typowymi reprezentantami epoki, w której przyszło im żyć, a to, że przez długi czas towarzyszyła im zła sława, którą zawdzięczali nie tyle faktycznemu nadzwyczajnemu okrucieństwu, a raczej temu, że ich adwersarze zdecydowanie górowali nad nimi w możliwościach kreowania tego obrazu.

\section{Bibliografia}

\section{ŹRÓDEA DRUKOWANE}

Aenae Sylvii Chronicon Bohemiae, [w:] Fontes Rerum Bohemicarum, t. VII, ed. J. Emler, Praha 1907. Archiv Český čili stare písemné památky České i Moravské, část 7, ed. F. Kalousek, Praha 1887.

Bartošek z Drahonic, Kronika, [w:] Ze správ a kronik doby husitské, oprac. I. Hlaváček, Praha 1981, s. 231-299.

Chronik des Martin von Bolkenhain, Scriptores Rerum Silesiacarum, Bd. XII (Geschichtsschreiber Schlesien des XV. Jahrhunderts), hrsg. F. Wachter, Breslau 1883.

Chronicon Bartossek de Drahonicz, [w:] Fontes Rerum Bohemicarum, t. V, ed. J. Goll, Praha 1893, s. 591-628.

Chronicon veteris Collegiati Pragensii, [w:] Fontes Rerum Austiacarum, Bd. II, Abt. 1, hrsg. K. Höfler, Wien 1856, s. 67-102.

Duchem i mečem. Čteni o slavě, velikosti a utrpeni našeho lidu, oprac. F. Heřmanský, Praha 2008. Jana Długosza Roczniki, czyli kroniki sławnego Królestwa Polskiego, ks. 11 i 12, Warszawa 2009. Joannis Dlugossi Annales seu cronicae incliti Regni Poloniae, Warszawa 2001.

Kronika velmi pěkná o Janu Žižkovi, [w:] Staročeské vojenské řády: Hájek - Vlček - Žižka, wyd. F. Svejkovský, wstęp J. Durdík, Praha 1952.

${ }_{32}$ J. Dolejší, L. Kř́ížek, op. cit., s. 225.

${ }_{33}$ M. Wilczyński, Czy Wandalowie byli wandalami?, [w:] Studia classica et byzantinica. Alexandro Krawczuk oblata, red. J. Salamon, Z.J. Kapera, Kraków 1996, s. 198-202, 209-215. 
Vavřinec z Březove, Husitská kronika, wyd. M. Bláhova, F. Heřmanský, Praha 1979.

Ze starých latopisů českých, wyd. J. Porák, J. Kašpar, Praha 1980.

\section{OPRACOWANIA}

Brych V., Arma diaboli. O kuši a střelcích, Praha 2012.

Bylina S., Rewolucja husycka, t. II (Czas chwaty i czas zmierzchu), Warszawa 2015.

Čornej P., Lipanská křižovatka. Přičiny, prủběh a historický význam jedné bitvy, Praha 1992.

Čornej P., Lipany ve svédectví pramenů, „Husitský tabor” 1985, t. VIII, s. 155-184.

Čornej P., Tajemství českých kronik, Vyšehrad 1987.

Čornej P., Velké dějiny zemi Koruny České, t. V (1402-1437), Praha 2000.

Dolejší J., Křížek L., Husité. Vrchol válečného umění v Čechách 1419-1434, Praha 2009.

Karp P., Niszczenie klasztorów w relacjach kronik doby wojen husyckich, [w:] Scriptura, diploma, sigillum. Prace ofiarowane profesorowi Kazimierzowi Bobowskiemu, red. J. Zdrenka, J. Karczewska, Zielona Góra 2009, s. 309-321.

Karp P., Polsko-husycka wyprawa zbrojna przeciw Zakonowi krzyżackiemu w roku 1433, Zielona Góra 2017.

Palacký F., Dějiny národu českeho v Čechach a na Moravě, t. III, wyd. 3, Praha 1940.

Siatkowska E., Siatkowski J., Wybór tekstów staroczeskich, wyd. 2, Warszawa1988.

Šmahel F., Husitská revoluce, t. III (Kronika válečných let), wyd. 2, Praha 1996.

Wilczyński M., Czy Wandalowie byli wandalami?, [w:] Studia classica et byzantinica. Alexandro Krawczuk oblata, red. J. Salamon, Z.J. Kapera, Kraków 1996, s. 197-216.

\section{Piotr STRZyż}

\section{„Men blackened with sun and charred with wind, with a horrible and terrifying look" - Hussite warriors in the light of contemporary sources}

\footnotetext{
$T$ he period of the Hussite revolution in the years 1419-1436 holds one of the most prominent places in the history of the Czech military. There is no doubt that this is also a time of great glory of Hussite field troops - the „Orphans” and the „Taborites”. For one and a half of a decade no contemporary army which confronted them was able to defeat the Hussites. However, the present paper will not deal with weaponry of these warriors. What will be discussed is their appearance and deeds, with special reference to those of non-military nature which very soon added to their sinister fame. It was not infrequently that this fame virtually paralysed entire armies and defenders of castles and towns - the very sound of a Hussite war battle song Ktož jsú boži bojovníci was enough. A sort of Hussite „hallmarks" were: burning and pulling down of monasteries and churches, tortures and murders of rural and urban populations, with a special preference for burning on the stake or in barns, as well as pillaging of any sort of movable and immovable property and trade with such goods. In spite of the fact that such acts were not uncommon in the Middle Ages, it was the Hussites who were very eagerly labelled as merciless plunderers.
}

Keywords: Kingdom of Bohemia, Hussites, Hussite revolution, Middle Ages, war. 